\title{
LANGUAGE AND POWER IN A WTO DIRECTOR -GENERAL'S SPEECH - A CRITICAL DISCOURSE ANALYSIS
}

\author{
Dang Thi Mai Nga* \\ Haiphong University, \\ 171 Phan Dang Luu, Kien An, Hai Phong, Vietnam \\ Received 22 August 2019 \\ Revised 13 November 2019; Accepted 23 December 2019
}

\begin{abstract}
The paper is aimed at exploring ideological power relations of globalization discourse through the analysis of the speech 'The Backlash against Globalization' of WTO's Director-General Mike Moore based on one of the Discourse Analysis (DA) approaches - Critical Discourse Analysis (CDA). At first, the paper sets out the theoretical framework of CDA and the concepts of power and ideology and examines the importance of Systemic Functional Grammar (SFG) in CDA. Then the paper provides readers with the social context of globalization and analyzes the speech in the light of $\mathrm{CD}$. The findings and the conclusion of the paper prove the assumption that the speech is a tool for Director-General Mike Moore to express his power and ideology in the sense that he is in higher position and confirms that globalization is inevitable and the establishment of WTO is a product of this process helping countries, communities and people face the problems and challenges.
\end{abstract}

Key words: CDA, language, ideology, power, SFG

\section{Introduction}

The world has seen profound economic and social changes on a global scale in the past twenty years. These changes bring not only opportunities but also challenges to many people. These changes have also had profound influence on our sense of self and place, causing considerable confusion and what has been widely referred to as a loss of meaning (Baudrillard 1983, 1993; Featherstone 1995). Globalization - a real but incomplete process- brings benefits to some people and hurts others. Supporters of this new world order view it as an inevitable and irreversible process which brings a lot of benefits to people and communities. Opponents believe that this new order increases inequality within and between nations, threatens employment and living standards and thwarts social progress. People who benefit from it try to extend it by using different resources such as discourse of globalization as well as other potent resources (donations to political parties). In this paper discourse of globalization is thus considered as discourse of power used by those in power to enhance their power. Therefore, in analyzing these changes and new phenomena, the questions of power are always taken into consideration. In order to find out the relationship of language and power in our contemporary world, Critical Discourse Analysis (CDA) is considered an important tool as what Fairclough (2001, p.25) stated: 'This is an opportunity and a challenge for critical language study - it can make a considerable contribution on issues which are vitally important for the future of humankind'.

\footnotetext{
Tel.: 84-919010681
}

Email dangmainga1981@gmail.com 


\section{Theoretical background}

\subsection{What is Critical Discourse Analysis?}

In 'An Introduction to Critical Discourse Analysis in Education', Gee (2004, p.19) emphasizes that 'in fact critical discourse analysis argues that language in use is always part and parcel of, and partially constitutive of, specific social practices, and that social practices always have implications for inherently political things like status, solidarity, distribution of social goods, and power'.

Fairclough (1993: 135) gives a definition of CDA by stating "By 'critical' discourse analysis I mean discourse analysis which aims to systematically explore often opaque relationships of causality and determination between (a) discursive practices, events and texts, and (b), wider social and cultural structures, relations and processes; to investigate how such practices, events and texts arise out of and are ideologically shaped by relations of power and struggles over power; to explore how the opacity of these relationships between discourse and society is itself a factor securing power and hegemony".

From these statements, it can be seen that CDA mainly focuses on the question of language and power as language is an important element of social life.

\subsection{Key concepts in $C D A$}

Having deep understanding about CDA requires us to get used to some key concepts of CDA like ideology and power since the notion of ideology and power are all seen as relevant for an interpretation or explanation of text.

\section{Ideology}

Wodak (2001) has pointed out that the concepts of ideology first appeared in late eighteenth-century France (Thompson, 1990) and has thus been in use for about two centuries. According to Thompson (1990), ideology refers to social forms and processes within which, and by means of which, symbolic forms circulate in the social world. Ideology is an important aspect of establishing and maintaining unequal power relation. CL takes a particular interest in the ways in which language mediates ideology in a variety of social institutions.

For Thompson (1990), the study of ideology is the study of the way in which meaning is constructed and conveyed by symbolic forms of various kinds. This study also investigates the social contexts within which symbolic forms are used and not used.

\section{Power}

The question of language and power is always taken into consideration especially in modern times with a lot of profound social and economic changes. The question of language and power serves to understand the new order.

For CDA, language is not powerful on its own - it gains power by the use of powerful make of it. Wodak (2001) explains why CDA often chooses the perspectives of those who suffer and critically analyses the language use of those in power, those who are responsible for the existence of inequalities and who also have the means and the opportunity to improve conditions.

Power is about relations of differences, particularly about the effects of differences in social structures. Language is entwined in social power in a numbers of ways: language indexes power, expresses power, is involved where there is contention over and a challenge to power.

\subsection{Systemic Functional Linguistic in Critical Discourse Analysis}

In this part, I will discuss systemic functional grammar and the reasons why FSL is used in CDA.

Fairclough and Chouliaraki (1999, p.139) explain that 'and especially the linguistic theory which we believe has the most in common with CDA and most to offer CDA, systemic functional linguistic (SFL)' and 'the version of CDA which we work with ourselves 
has used SFL as its main resource for textual analysis'.

Fairclough (1999, p.139) points out a 'complementary relationship' between SFL and CDA as follows:

'SFL is profoundly concerned with the relationship between language and other elements and aspects of social life, and its approach to the linguistic analysis of texts is always oriented to the social character of text... This makes it a valuable source for critical discourse analysis, and indeed major constructions to critical discourse analysis have developed out of SFL'.

For Fairclough and Chouliaraki (1999, p.139), SFL 'views language as a semiotic system which is structured in terms of strata. Language connects meanings (the semantic stratum) with their spoken and written expressions (the stratum of phonology and graphology). Both meanings and expression interface with the extra-linguistics.'

The relationship between strata is one of 'realisation': each of the strata defines a potential, a set of possibilities - a meaning potential (semantics), a wording potential (lexicogrammar), an expression potential. This relationship can be extended in the 'context of situation'. The context of situation can be specified in terms of possible values for three variables - the field (the activity which the language is part of), the tenor (the social actors involved and the relation between them), and the mode (the part language plays in the activity) corresponding respectively the ideational, interpersonal and textual macrofunctions. More specifically, the macrofunctions covers ideational function (language in the construction and representation of experience in the world, the interpersonal function (language in the enactment of social relations and the constructions of social identities) and the textual function (language in the specifically semiotic-textual-form of productive practice). In SFL, lexicogrammar is seen as functionally grounded, shaped by the social functions it serves, and in particular built around the intersection of the 'macrofunctions' of language. Corresponding to these three macrofunctions are three major networks of grammatical system which are transitivity, mood and modality, and information including theme-rheme and given-new. Fairclough and Chouliaraki (1940, p.140) state that:

"Every clause in the text (as well as lower and higher-level grammatical units) is seen as grammatically constituted simultaneously as semiotic production (textual function) which constructs the world (ideational function) while enacting social relations between its producers and others who inhabit the world (relational function). Thus the social is built into grammatical tissue of language... so that the semiotic constitution by the social and of the social is constantly at issue in the language analysis".

Concerning three macro-functions of language, I find two macro-functions relevant to this study. They are the Experiential function and the Textual function. The two functions at the discourse - semantic level are realized at the lexico-grammar represented by choices in the Transitivity and Thematic system and the unit of this level is the clause.

\section{Social context of globalization}

\subsection{What is globalization?}

According to Fairclough (2001, p.205), 'globalization is first an economic process, and the neo-liberal doctrine it is currently associated with is centred upon maximally free trade - the free movement of goods, finance and people internationally. What is involved is a shift in the relationship between the market and the state which characterized capitalism for most of the twentieth century, freeing the market from state controls and undermining the role of the state in providing social welfare, and converting the state into a local advocate and agent for free market.' 


\subsection{Globalization from different perspectives}

\subsubsection{Opportunities and possibilities}

Globalization offers opportunities to many countries. Global markets offer more opportunities people have more chances to access capital flows, technology, cheaper imports and lager export markets.

In the speech 'Making Globalization work', Director-General Mike Moore stated:' What are the most important issues for people across the globe? Life expectancy, hunger and poverty reduction, access to clean drinking water, democracy, a better living environment. And on almost every useful measurement of the human condition, we have seen the greatest advances in the history of our species during the last half century, according to data collected by the UNDP and other agencies.

\subsubsection{Constraints and difficulties}

Globalization is also considered the major cause of social and environmental problems in many countries. Unskilled workers will face increasing competition across border. Workers in some developing countries are losing their jobs to their counterparts. Many conservationists argue that international integration encourages the overexploitation of fragile natural resources, such as forests and fisheries, damaging the livelihoods of the poor. They claim that the International Monetary Fund (IFM) and the World Bank (WB) are the major causes of poverty in many countries today. In fact, The IMF and WB are largely owned and controlled by the developed countries such as the USA, German, the UK, and Japan. Receiving assistance from IMF and WB the economic direction of these countries would be planned, monitored and controlled by these organizations or countries.

\section{Findings}

\subsection{Analysis in terms of vocabulary used}

According to Fairlcough (2001, p.94), "the aspect of experiential value of most interest in the context of this book is how ideological differences between texts in their representations of the world are coded in their vocabulary". In extending the opportunities of globalization process, Director-General Mike Moore tries to portrait globalization as a bright process with a lot of good things such as free market, open and prosperous world, richer, big profits, free trade, promotes freedom and buttresses our security and peace.

Director-General Mike Moore also tries to persuade the audience by giving the persuasive figures in the following paragraph:

The World Trade Organization, and its predecessor the GATT, has played an important role in creating this more open and prosperous world. Since the GATT was set up in 1948, world trade has soared 15-fold, to more than $\$ 7,000$ billion a year. This has helped to multiply world output by seven. This huge rise in living standards has allowed nearly everyone to enjoy the luxuries that were previously enjoyed only by the few. European tours were once the preserve of British aristocrats. Now almost everyone in the EU can enjoy a foreign holiday. Even in poor countries, people live longer, eat better, and have more access to clean water than they did 50 years ago. GDP per head in less developed countries has trebled since 1950, life expectancy has risen by over 20 years, and adult literacy rates have increased by over 30 percentage points: (lines 107 - 117)

From the above paragraph, it can be seen that thanks to the establishment of WTO, there have been a lot of changes in different fields.

Director-General Mike Moore portraits two pictures of the world in 1949 and 1980:

In 1949, when I was born, trade barriers were still at their post-Depression highs, few currencies were convertible, rationing was commonplace, huge swathes of industry were nationalized. (line 10 - 13)

But in the 1980s things changed. In rich countries such as the United States, Britain and my own country, New Zealand, governments embraced liberal ideas. National champions 
were discarded in favour of international competition. Industries were privatised and markets deregulated. Capital controls were abolished. Foreign investment was welcomed with open arms: (lines 17 - 22)

The focus of relational value is how the text's choice of wordings depends on, and helps create, social relationships between participants.

In this speech, Director-General Mike Moore confirms that globalization is an inevitable process even some people are still skeptical about the process of globalization as well as the operation of WTO by giving the following evidence:

An ugly new word, globalization, was coined to describe this process. It seemed inevitable; even those who harboured doubts about globalization thought opposition was futile. (lines 28 - 30)

In his speech, Director-General Mike Moore is fully aware of the fact that people are against globalization 'But there has been a backlash against liberalism. For a start, statist urges are alive and well. The traditional calls for intervention to "save" jobs or redistribute wealth still strike a chord. Moreover, many people dislike the fact that seemingly impersonal market forces hold sway over their lives, even though markets in fact reflect the combined preferences of millions of ordinary people"" (lines 46 - 50)

$\mathrm{He}$ also understands that 'Some people lose from change, and many more fear they might lose: (lines 61 - 62)

He reminds people of that fact 'But we should also remember that a century ago, people fretted at the massive shift off the land and into the factories, but that people nowadays are much richer thanks to the Industrial Revolution.' (lines 63 -65). By reminding people of this matter he would like to imply that thanks to globalization and other changes in our world people just have the chance to have better life.

Director-General Mike Moore continues listing the challenges and difficulties that people face as a result of globalization 'Of course, some people do lose in the short run from trade liberalization. But others are poor farmers who lose their subsidies or unskilled workers who lose their jobs.' (lines 118 - 120).

The way to deal with these challenges is that 'But the right way to alleviate the hardship of the unlucky few is through social safety nets and job retraining rather than by abandoning reforms that benefit the many.' (lines 121 - 123) Once again, Director-General Mike Moore wants to help people fully understand the role of globalization in coping with 'the hardship of the unlucky few'.

When talking about the need of establishing WTO, he points out 'If the WTO did not exist, people would be crying out for a forum where governments could negotiate rules, ratified by national parliaments, that promote freer trade and provide a transparent and predictable framework for business. And they would be crying out for a mechanism that helps governments avoid coming to blows over trade disputes. That is what the WTO is.' (Lines 134 - 138). With these statements, he confirms the necessity of establishing WTO as a result of globalization process.

Classification scheme constitutes a particular way of diving up some aspects of reality which is built upon a particular ideological representation of that reality. The structure is thus ideological based.

Referring to the globalization and free trade he mainly uses the positive words: liberal and open place, open economic principles, benefits of openness, trade liberalization, free trade.

In contrast, he mainly uses the negative words when referring to the situation of the world before the time of globalization: trade barrier, the pace of liberalization was slow and its scope limited.

Over-wording (over-lexicalization) shows preoccupation with some aspects of reality - which may indicate that is a focus of ideological struggle.

A number of words and phrases which are 
near synonyms expressing his ideology about liberalism are used: economic liberalization, liberal democracy, liberalism, economic liberalism, liberalization, free trade, opening, openness, trade liberalization.

\section{Haboured doubt about globalization \\ Protectionist nightmare Unlucky few}

line $29><$

\section{line $83><$ Long boom}

line $122><$ Benefit the many
What is the use of employing autonymy? These antonymous words and phrases put in parallel structure express his ideology about presenting a contrasting picture: the difficulties and possibilities before and after globalization.

The triumph of liberal democracy line 31

Delivering this speech at a formal situation demands the formality of social relations and it is evident in his speech

It is a great pleasure

... put national cultural on a pedestal $\cdots$

That's why I make a point of testifying before parliamentary committees

When delivering this speech, DirectorGeneral Mike Moore is fully aware of the fact that a number of people in different countries and communities still consider globalization and WTO as the causes of poverty and inequality all over the world. The formal choices of words and phrases demonstrate his high position and express his concern for the audience face.

\subsection{Analysis in terms of grammatical features}

\subsubsection{The use of personal pronoun}

The use of personal pronoun $\boldsymbol{I}$ is found when Director-General Mike Moore expresses his own idea and experience. This makes the speech more persuasive as this seems to base on his personal experience.

Table 4. Instance of the use of $I$ in the text

\begin{tabular}{|c|c|}
\hline Line 2 & $\begin{array}{c}\text { I think it is vitally important that we reconnect international organizations with the } \\
\text { political grassroots. }\end{array}$ \\
\hline Line 4 & That is why I am here to report back to you as well as to listen to your concerns. \\
\hline Line 4 & $\begin{array}{c}\text { I have made a point of meeting with elected representatives from the Socialist } \\
\text { International and the Democratic Union. }\end{array}$ \\
\hline Line 8 & $\begin{array}{c}\text { If I had made this speech a few years ago, my them would probably have been "The } \\
\text { Triumph of Economic Liberalism." }\end{array}$ \\
\hline Line 10 & $\begin{array}{l}\text { When I was born, trade barriers were still at their post-Depression highs, few } \\
\text { currencies were convertible, rationing was commonplace, huge swathes of industry were } \\
\text { nationalized, and Soviet communism threatened to crush liberal democracy. }\end{array}$ \\
\hline Line 40 & I am not suggesting that liberalism is in retreat. \\
\hline Line 52 & $\begin{array}{c}\text { In my own country, I used to lecture unions that profit was a good word, that the only } \\
\text { real security for workers was a healthy balance sheet, and that they should not attack } \\
\text { companies that made big profits but picket incompetent managers who endangered } \\
\text { workers'futures by making losses. }\end{array}$ \\
\hline Line 82 & $\begin{array}{l}\text { I think the most important lesson of the past } 50 \text { years is that we must embrace the outside } \\
\text { world, not shun it. }\end{array}$ \\
\hline Line 90 & $\begin{array}{c}\text { I love my country, but I see no reason why I shouldn't also enjoy the best that other } \\
\text { countries have to offer. }\end{array}$ \\
\hline Line 145 & $\begin{array}{l}\text { That is why I make a point of testifying before parliamentary committees whenever I visit } \\
\text { a country. And that's one of the reasons I'm here today. }\end{array}$ \\
\hline
\end{tabular}


In contrast, when attracting the attention in globalization process, he mainly uses and calling the responsibility for cooperating personal pronoun we.

Table 5. Instances of the use of $w e$ in the text

\begin{tabular}{|c|c|c|}
\hline Line 3 & We reconnect international organizations & Exclusive \\
\hline Line 6 & We need to connect & Exclusive \\
\hline Line 62 & We must ensure that they receive & Exclusive \\
\hline Line 63 & We should remember & Exclusive \\
\hline Line 78 & We shall never convince & Exclusive \\
\hline Line 70 & We must not allow & Exclusive \\
\hline Line 80 & We need to make & Exclusive \\
\hline Line 128 & We owe it to them & Inclusive \\
\hline Line 130 & We are too often misunderstood & Inclusive \\
\hline Line 131 & We are not a world government & Inclusive \\
\hline Line 139 & We do not lay down the law & Inclusive \\
\hline Line 139 & We uphold the rule of law & Inclusive \\
\hline Line 142 & We need to put & Inclusive \\
\hline Line 142 & We also have to listen & Inclusive \\
\hline Line 143 & We are trying to & Inclusive \\
\hline Line 144 & We are constantly & Inclusive \\
\hline Line 145 & We welcome & Inclusive \\
\hline
\end{tabular}

The personal pronoun we can be inclusive (the reader as well as the writer) or exclusive (the writer (or speaker) plus one or more others, but does not include the addressees). From the above examples, it can be seen that DirectorGeneral Mike Moore uses all the exclusive we when referring to the responsibility and cooperation of people in different countries and communities, conveying his solidity with the audience to emphasize that it is their

Table 6. instances of the use of they in the text

\begin{tabular}{|c|c|}
\hline Line 53 & That they should not attack companies that made big profits \\
\hline Line 60 & $\begin{array}{c}\text { But now in our media age, people are constantly confronted with change that they would } \\
\text { otherwise not be aware of. }\end{array}$ \\
\hline Line 77 & And they take aim at the WTO because they see it as the handmaiden of globalization. \\
\hline
\end{tabular}

When referring to people who are on the same boat, extending the bright future of globalization, Director-General Mike Moore employs the personal pronoun we. In contrast, by using the personal pronoun they, he wants the audience to identify some responsibility to struggle for globalization while the use of inclusive we is found when he mentions their organization -WTO.

Delivering this speech, General-Director Mike Moore would like to express his idea about the fact that there has been a backlash against liberalism so the use of personal pronoun they can be found in this speech: groups of people blaming the process of globalization and WTO. 


\subsubsection{The use of voice}

Table 7. Number and percentage of passive and active sentences used in the text

\begin{tabular}{|c|c|c|}
\hline Voice & Time appeared & Percentage (\%) \\
\hline Passive & 8 & $7 \%$ \\
\hline Active & 106 & $93 \%$ \\
\hline Total & 114 sentences & $100 \%$ \\
\hline
\end{tabular}

In terms of voice, only 8 passive sentences accounting for $7 \%$ are found in comparison with 106 active sentences accounting for 93\% among 114 sentences. The use of high percentage of active sentences can be a good explanation for his ideology when delivering this speech. The active sentences make the meaning of the speech clearly stated so that what the speaker wants to covey to his audience can easily access the mind of the audience. Obviously, it is a good way to avoid misunderstanding and ambiguity for his audience.

The use of active sentences supports the fact that WTO plays an active role in assisting people to cope with the difficulties and constraints like in the following examples:

We need to make the case for freedom, economic, political, and social, again and again: (Lines 80-81)

The World Trade Organization, and its predecessor the GATT, has played an important role in creating this more open and prosperous world: (Lines 107-108)

Only 8 sentences are used in passive voice but contributing much in conveying the speaker's ideology:

National champions were discarded in favour of international competition. Industries were privatised and markets deregulated. Capital controls were abolished. Foreign investment was welcomed with open arms. These policies were copied not only in other industrialised countries, but also in many developing ones, and then, after the collapse of communism, in ex-communist ones. (Lines 19-24)

By using passive voice in these clauses Director-General Mike Moore attracts the attention of the audience about the achievements thanks to the renovation.

\subsubsection{Moods of the sentences}

Three kinds of moods - declarative, imperative and grammatical questions are all found on this speech. According to Fairclough (2001) 'these three modes positions subjects differently. In the case of a typical declarative, the subject position, the subject position of the speaker/writer is that of a giver (of information), and the addresser's position is that of a receiver. In the case of the imperative, the speaker/writer is in the position of asking something of the addressee, while the addressee is a compliant actor. In a grammatical question, the speaker/writer is again asking something of the addressee, in this case information, and the addressee is in the position of a provider of information'.

Accounting for $99 \%$ of the speech, declaratives help us recognize that the speech focuses on giving information. With declarative the speaker wants to confirm that it is him who has the right to include or exclude in giving such information and the addressee's position is that of the receiver.

In this speech only one clause is employed in imperative mood 'Just compare the protectionist nightmare of the 1930s with the long boom in America and Europe in the 1950s and 1960s' (Lines 83-85) in comparison with other clauses employing declarative mood helps us know that all the speaker wants to emphasize is the importance and the benefits that globalization brings to.

Only one question found in this speech is in the title of the speech 'the Backlash against Globalization?' The explanation for this phenomenon is the discourse type as 
in a discourse of giving a speech, questions may not be abundantly found because of less chance of getting feedback. Moreover, questions (if any) may fall to rhetorical types. The question of this speech helps to uncover the ideology of the speaker because beginning the speech with a question mark, the speaker seems to help people to find out the answer. In fact, the speaker himself gives the answer by his speech.

\subsubsection{Modality}

Modality is to do with speaker or writer authority, and there are two dimensions to modality: relational and expressive. By relational modality, we mean it is a matter of the authority of one participant in relations to others; it is the matter of the speaker or writer's authority with respect to the truth or probability of a representation of reality.

The use of must conveys GeneralDirector Mike Moore's power, his authoritative position; and the power, that authoritative position them, are exerted on the audience the addressee is required to perform the action he asks them to do.

But we must not allow the zealots and self-serving privileged people to discredit liberalism among the wider public. (Lines 78 80)

We must embrace the outside world. (Lines 82-83)

We must ensure that they receive help to adjust. (Lines 62-63)

It is their responsibility is to help the people who 'lose from change, and many more fear they might lose' some groups of the audience that the rich will help them to adjust.

We need to connect better and be more accountable to our owners, governments, and work closer with legislators. (Lines 6-7)

In the context of "The Backlash against Globalization" We need to make the case for ........ (Line 80)

Need in these sentences is used as an ordinary verb equivalent to have to is a way of telling them what is necessary in the situation.

Of course, we need to put our case better.
We also have to listen to our critics more. (Lines 142-143)

The use of should is also found in this speech conveying the obligation meaning in the following sentences:

They should not attack companies that made big profit. (Lines 53-54)

But we should also remember that a century ago, people fretted at the massive shift off the land and into the factories, but that people nowadays are much richer thanks to the Industrial Revolution. (Lines 63-65)

Director-General Mike Moore wants to remind the audience that many people benefit from globalization: If the WTO did not exist, people would be crying out for a forum where governments could negotiate rules, ratified by national parliaments, which promote freer trade and provide a transparent and predictable framework for business. And they would be crying out for a mechanism that helps governments avoid coming to blows over trade disputes. (Lines 134-138)

The use of would in the conditional sentence type describes the unreal things to confirm that the establishment of WTO is obvious during the process of globalization.

\subsubsection{Connectives values of the text}

Fairclough (2001) shows that connective values are the values formal features have in connecting together parts of texts. It is to do with the relationship between texts and contexts. Formal items with connective value have other values at the same time.

Cohesion can involve vocabulary links between sentences-repetition of words, or the use of related words and connectors which mark various temporal, spatial and logical relationships between sentences.

\section{Repetition}

The words and phrases repeated in the speech help us recognize the speaker's ideology. Here are some most important words and phrases that appear with high degree of frequency in the speech:

Globalization (lines 28, 30, 38, 56, 70, 74, 77, 95, 102) 

139)

WTO (lines 37, 43, 77, 107, 130, 133, 134,

Liberalization (lines 14, 118)

Liberalism (Lines 78, 80)

Openness (Lines 83, 86, 97)

The focus on 'globalization' is clearly found in different contexts with the hope that the globalization is an inevitable process in modern time and it is globalization that brings a lot of benefits to all countries, communities and people.

Along with globalization is WTO so the repetition of $\boldsymbol{W T O}$ makes people form the concept of an organization as well as its significant role in helping all the countries, communities and people coping with the difficulties happening in the process of globalization.

\section{Connectors}

Fairclough (2001:109) stated that logical connectors 'can cue the ideology assumption' so in this part we will analyze the connectors used in the speech to discover how they cue the ideology of Director-General Mike Moore.

In terms of connectors, the most common case of connectors observed in this text is the use of connector ' $b u t$ ' like in the following examples:

Industrialised countries made their currencies convertible and freed up trade among them, but governments maintained a tight grip on capital flows and continued to intervene in the domestic economy. But in the 1980s things changed. (Lines 15-17)

Director-General Mike Moore draws two pictures of the world through different periods so the audience can compare and come to their own conclusion that the world has achieved the advancements thanks to the fact that 'In rich countries such as the United States, Britain and my own country, New Zealand, governments embraced liberal ideas.' (Lines 18-19)

Director-General Mike Moore lists all the changes caused by 'liberal ideas' like 'National champions were discarded in favour of international competition.
Industries were privatised and markets deregulated. Capital controls were abolished. Foreign investment was welcomed with open arms. '(Lines 19-22)

The rest of the speech serves the purpose that a lot of achievements can be made thanks to globalization.

He is aware of the fact that 'But there has been a backlash against liberalism.' (Lines 46)

Globalization is not new, but it is more pervasive than before. (Lines 56-57)

Throughout the past century, new technologies have continuously caused upheaval. But now in our media age, people are constantly confronted with change that they would otherwise not be aware of. This helps opportunistic populists whip up fears of change. (Lines 58-61)

Of course, some people lose from change, and many more fear they might lose. We must ensure that they receive help to adjust. But we should also remember that a century ago, people fretted at the massive shift off the land and into the factories, but that people nowadays are much richer thanks to the Industrial Revolution. (Lines 61-65)

But the benefits of openness are not only economic.' (Line 86)

Connector can also be found in sentence with 'yet'

The WTO is a powerful force for good in the world. Yet we are too often misunderstood, sometimes genuinely, often willfully. (Lines 130-131)

The connector ' $y e t$ ' expressing the contrasting idea is used to link two sentences so what the speaker wants to imply is that despite working for the world WTO is often misunderstood and it is not fair if people often blame WTO as the cause of poverty. It is the reason why he raises the awareness of people of WTO's role and the benefits it brings.

\subsection{Analysis in terms of Transitivity}

The speech is divided into 191 simple clauses. The participants and process types will be presented in the appendix. 
Table 8 . Summary of transitivity analysis data

\begin{tabular}{|c|c|c|}
\hline Types of process & No appeared & Percentage (\%) \\
\hline Material & 103 & $53.9 \%$ \\
\hline Relational & 58 & $30.4 \%$ \\
\hline Mental & 21 & $11 \%$ \\
\hline Existential & 4 & $3.7 \%$ \\
\hline Behavior & 0 & $0 \%$ \\
\hline Verbal & 2 & $1.4 \%$ \\
\hline
\end{tabular}

In terms of transitivity material process - the process of doing and narrating things accounts for the largest percentage: $53.9 \%$. Looking at these clauses of material process helps us arrive some interesting findings. The high percentage of material process indicates that the speaker's aim is to describe the actions and events. As mentioned before, supporters of globalization point to its huge capacity for wealth creation, assuming that while some may gain more than others, all will gain to some extent. People who benefit from this process seek to extend it. In this speech Director-General Mike Moore places an emphasis on the benefits of globalization as well of establishing and accessing WTO.

This has helped to multiply world output by seven. This huge rise in living standards has allowed nearly everyone to enjoy the luxuries that were previously enjoyed only by the few. (Lines 110-112)

Even in poor countries, people live longer, eat better, and have more access to clean water than they did 50 years ago. GDP per head in less developed countries has trebled since 1950, life expectancy has risen by over 20 years, and adult literacy rates have increased by over 30 percentage points. (Lines 113-117)

It helps pay for the things we value most: jobs, health, education, a cleaner environment. And it promotes freedom and buttresses our security and peace. (Lines 124-126)

\subsection{Analysis in terms of Thematization}

Table 9. Summary of thematic analysis

\begin{tabular}{|c|c|c|}
\hline Type of theme & Times appeared & Percentage (\%) \\
\hline Topical & 112 & $70.4 \%$ \\
\hline Textual & 40 & $25.2 \%$ \\
\hline Interpersonal & 7 & $4.4 \%$ \\
\hline Total & 159 & $100 \%$ \\
\hline \multicolumn{2}{|c|}{ Times appeared } & Percentage (\%) \\
\hline Marked & 54 & $34 \%$ \\
\hline Unmarked & 105 & $66 \%$ \\
\hline Total & 159 & $100 \%$ \\
\hline
\end{tabular}

\begin{tabular}{|c|c|c|}
\hline Types of topical themes & Times appeared & Percentage (\%) \\
\hline Marked topical themes & 8 & $7.14 \%$ \\
\hline Unmarked topical theme & 104 & $92.9 \%$ \\
\hline Total & 112 & $100 \%$ \\
\hline
\end{tabular}

From these above tables, it is easily seen that topical themes and unmarked type account for a high percentage of the total themes in the speech. The topical themes create the focus on the 'backlash' and 'globalization'. 
Table 10. Summary of topical themes

\begin{tabular}{|c|c|}
\hline Backlash & Globalization \\
\hline Worries & The world economy \\
The setback & Openness \\
There & the benefits of openness \\
The traditional calls & Open societies \\
many people & Opening up \\
Another strand & Openness \\
the biggest challenge & The World Trade Organization \\
Some people & This huge rise \\
The problem & Free trade \\
Those people & The WTO \\
\hline
\end{tabular}

$33.96 \%$ marked themes falling into the category of temporal adverbials help the speaker to focus on the specific time of the events.

The speech also observes the little use of interpersonal themes $(4.4 \%)$ in comparison with topical (70.4\%) and textual ones (25.2\%). The answer to this phenomenon is the type of discourse and the speaker's ideology. The type of discourse is giving a speech so there is hardly any interaction between the speaker and his audience. The speaker's ideology plays a more important role in finding out the answer to this matter in the sense that the speaker aims to keep a distance from the audience and it helps to reinforce his authoritativeness.

\subsection{Analysis in terms of the macro-structure of the text}

If the previous parts of this study try to uncover the speaker's ideology hidden behind words from the microstructure perspective by breaking the speech into small units like vocabulary, grammar, cohesive devices, and grammatical features, this part will look at the macro-structure of the text to understand communicative purposes of the speaker.

Globalization itself is a controversial issue of many debates. Whenever WTO holds talks there have been a lot of demonstrations. The speaker tries to arrange the ideas so that both sides of the issues are examined and come to a conclusion in which the writer weighs the pros and cons of each side.
The speech begins with the title 'The Backlash against Globalization?' so the macro-structure of the text serves the speaker's ideology by its anti-thesis organization.

Director-General Mike Moore starts the speech with the picture of the world in the past, the situations we were in over 20 years ago.

At first, the pace of economic liberalization was slow and its scope limited. Industrialised countries made their currencies convertible and freed up trade among them, but governments maintained a tight grip on capital flows and continued to intervene heavily in the domestic economy. (Lines 14-17)

\section{But in the 1980s things changed.}

After this point of time the world saw a lot of differences in different fields in society:

In rich countries such as the United States, Britain and my own country, New Zealand, governments embraced liberal ideas. National champions were discarded in favour of international competition. Industries were privatised and markets deregulated. Capital controls were abolished. Foreign investment was welcomed with open arms. (Lines 18-22)

In that context, the term 'globalization' appeared to describe this process as the inevitable result.

'But there has been a backlash against liberalism.' (Lines 46)

Following this statement is the evidence 'For a start, statist urges are alive and well. The traditional calls for intervention to "save" jobs or redistribute wealth still strike a 
chord. Moreover, many people dislike the fact that seemingly impersonal market forces hold sway over their lives, even though markets in fact reflect the combined preferences of millions of ordinary people. And there is a widespread distrust of the profit motive, as if making losses was preferable.'(Lines 46-51).

From that point, the speaker develops the speech in anti-thesis organization.

Another strand is people's fear of change. Globalization is not new, but it is more pervasive than before. A century ago, for instance, there was more cross-border migration than there is now. Throughout the past century, new technologies have continuously caused upheaval. (Lines 54-57)

But now in our media age, people are constantly confronted with change that they would otherwise not be aware of. (Lines 57-58)

or

Of course, some people lose from change, and many more fear they might lose. We must ensure that they receive help to adjust. (Lines 59-60)

But we should also remember that a century ago, people fretted at the massive shift off the land and into the factories, but that people nowadays are much richer thanks to the Industrial Revolution. (Lines 61-63)

or

We shall never convince such zealots of the case for economic liberalism. (Line 76)

But we must not allow the zealots and selfserving privileged people to discredit liberalism among the wider public. (Lines 76-78)

or

When South Korea's economy seized up, workers in Korean factories in Britain lost their jobs. Undeniably, this causes pain. (Lines 98-99)

But people tend to forget that, thanks to globalization, good times in the rest of the world spill over to us too. (99-100) or

Of course, some people do lose in the short run from trade liberalization. Some are fat cats grown rich from cosy deals with governments. (Lines 114-115)

But others are poor farmers who lose their subsidies or unskilled workers who lose their jobs. (Lines 115-116)

or

Their plight should not be forgotten. (Lines 116-117)

But the right way to alleviate the hardship of the unlucky few is through social safety nets and job retraining rather than by abandoning reforms that benefit the many. (Lines 117-119)

After examining two sides of the problem, the speaker comes to a conclusion that

People do not want a world government, and we do not aspire to be one. At the WTO, governments decide, not us. (Lines 128-129)

But people do want global rules. If the WTO did not exist, people would be crying out for a forum where governments could negotiate rules, ratified by national parliaments, that promote freer trade and provide a transparent and predictable framework for business. And they would be crying out for a mechanism that helps governments avoid coming to blows over trade disputes. That is what the WTO is. (Lines 130-134)

The conclusion reflects the ideology hidden in the speech when the speaker confirms the necessity of an organization like WTO.

\section{Conclusion}

Based on the analysis of this speech we can come to the following conclusions:

In terms of vocabulary, the discourse has a clear classification scheme which is presented by the bright side of globalization in contrast with the dark side of the whole world before globalization. 
In terms of grammatical features, the power and ideology of the speaker can also be uncovered. Thanks to the use of personal pronoun we the speaker would like to create solidarity among people but not forget to shirk personal responsibility with the use of personal pronoun $I$. Based on the use of mood and voice the speaker exerts his power over others in an indirect way.

The high percentage of material process in transitivity and topical theme in thematization serve the speaker's aim of describing actions and events.

From the macro-structure the ideology of the speaker can also be seen clearly with the anti-thesis organization of the speech. The development of the discourse is organized in the structure of pros and cons of the matter.

In brief, the speech is a tool for DirectorGeneral Mike Moore to express his power and ideology in the sense that he is in higher position and confirms that globalization is inevitable and the establishment of WTO is a product of this process helping countries, communities and people face the problems and challenges.

The application of the results of CDA research is important, as an underlying aim of CDA is to produce enlightenment and emancipation for those less powerful in society.

What is the relationship between the process of globalization and the discourse of globalization? This question takes us to an important issue the relationship of language and power in the contemporary world.

The establishment of WTO is a product of globalization and also a contribution to push up this process. To understand it, we need to refer to the nature of the power relations embodied by the whole world context of globalization. The owners of these organizations are powerful and rich countries benefiting a lot from the process of globalization try to strengthen their power and position. The speaker also emphasizes the role of WTO like helping people have better understanding, raising the awareness of the people of the globalization and the role of WTO.

All can be done by the use of language in the speech. In other words, language is used to serve the purpose of some groups of people conveying their ideology.

\section{References}

\section{Vietnamese}

Nguyễn Hòa (2003). Phân tích diễn ngôn - một số vấn đề lý luận và phương pháp. Hà Nội: NXB Đại học Quốc gia Hà Nội.

More, M. (2000). The Backlash against Globalization. Retrieved from http://www.wto/english/news_e/ spmm_e/spmm39_e.htm.

\section{English}

Brown, J.D. \& Rodgers, T.S. (2002) Doing Second Language Research. China: OUP

Chouliaraki L. \& Fairclough, N. (1999) Discourse in Late Modernity: Rethinking Critical Discourse Analysis. Edinburgh University Press, Edinburgh

Fairclough, N. (2001) Language and Power (second edition). Harlow: Longman

Fairclough, N. (1995) Critical Discourse Analysis: The Critical Study of Language. London: Longman

Faircough, N. and Wodak, R. (1997) 'Critical Discourse Analysis', in T. van Dijk (ed.), Discourse Studies: A Multidisciplinary Introduction. Volume 2. London: Sage, pp 258-84

Halliday, M.A.K. (1994) An Introduction to Functional Grammar. London: Edward Arnold

Halliday, M.A.K. \& Hasan R. (1976) Cohesion in English. London: Longman

Huynh, A.T (2017) Voices against socio-political inequality in Critical Discourse Analysis. VNU Journal of Foreign Studies, 33(3), 146-156.

Nguyen Thi Thu Ha (2004), A Critical Discourse Analysis of President Bush's Ultimatum to President Saddam Hussein, Unpublished M.A. Thesis, VNUCFL.Hanoi

Nunan, D. (1992) Research Methods in Language Learning. UK: CUP

Rogers, R. (2002) An Introduction to Critical Discourse Analysis in Education. London, Mahawah, New Jersey: Lawrence Erlbaum Associates Publishers

Wodak, R. and Meyer, M. (2001) Methods of Critical Discourse

Weiss, G. \& Woward, R. (2003) Critical Discourse Analysis: Theory and Disciplinary. Palgrave: Macmillan 


\title{
NGÔN NGŨ̉ VÀ QUYỀn LỰC TRONG BÀI PHÁT BIỂU CỦA TỔNG GIÁM ĐỐC TỔ CHỨC THƯƠNG MẠI THẾ GIỚI - PHÂN TÍCH DIỄN NGÔN PHÊ PHÁN
}

\author{
Đặng Thị Mai Nga \\ Truờng Đại học Hải Phòng, \\ Số 171 Phan Đăng Luu, Kiến An, Hải Phòng, Việt Nam
}

Tóm tắt: Bài viết này xem xét mối quan hệ giữa hệ tư tưởng và quyền lực dựa trên bài phát biểu của Tổng Giám đốc Tổ chức Thương mại Thế giới Mike More theo đường hướng phân tích diễn ngôn phê phán. Trước tiên, bài viết xem xét tầm quan trọng của Ngữ pháp chức năng hệ thống với phân tích diễn ngôn phê phán. Phần tiếp theo, bài viết cung cấp cho người đọc bối cảnh xã hội của toàn cầu hóa và phân tích bài phát biểu theo quan điểm của phân tích diễn ngôn phê phán. Kết quả phân tích làm rõ bài phát biểu được sử dụng như một công cụ để Tổng Giám đốc Mike More thể hiện quyền lực và hệ tư tưởng của mình. Theo đó, Tổng Giám đốc Mike More ở vị thế cao hơn và khẳng định toàn cầu hóa là tất yếu và việc thành lập tổ chức thương mại thế giới chính là sản phẩm của quá trình này nhằm giúp các đất nước, cộng đồng và mọi người đối diện với những khó khăn và thách thức.

Tù khóa: phân tích diễn ngôn phê phán, ngôn ngữ, hệ tư tưởng, quyền lực và ngữ pháp chức năng hệ thống. 